\title{
Taxonomy of Apenesia Westwood (Hymenoptera, Bethylidae) from Paraná, Brazil
}

\author{
Michelle Sarcinelli Leal ${ }^{1}$ \\ Celso Oliveira Azevedo ${ }^{1}$
}

\begin{abstract}
Apenesia quadrimera sp. n., A. rotunda sp. n. and A. clypeata sp. n. are described and illustrated. New geographic records and variation data of $A$. cusco Evans, 1966, A. distinta Corrêa \& Azevedo, 2001, A. funebris Evans, 1963, A. fusilis Corrêa \& Azevedo, 2001, A. inca Evans, 1963 and A. transversa Evans, 1963 are added.

KEY WORDS. Apenesia, Bethylidae, Hymenoptera, Paraná, Brazil
\end{abstract}

Apenesia Westwood, 1874 belongs to the subfamily Pristocerinae and has about 130 species, particularly abundant in the Neotropics, with 70 species (GORDH \& MOCZAR 1990). Thirty species are recorded to Brazil in the states of Amazonas, Pará, Mato Grosso, Minas Gerais, Espírito Santo, Rio de Janeiro, São Paulo, Santa Catarina and Rio Grande do Sul. The genus is here recorded for the first time to the state Paraná, with description of three new species, so that the Brazilian fauna of this genus is now composed by 33 species.

The material examined was provided by the Coleção de Entomologia Padre J.S. Moure, Universidade Federal do Paraná (DZUP). The nomenclature in this study follows Evans (1963). Main measurements and indices used are as follow: length of forewing (LFW); length of head (LH); width of head (WH); width of frons (WF); height of eye (HE); ocello-ocular line (OOL); width of ocelar triangle (WOT); diameter of anterior ocellus (DAO); vertex-ocular line (VOL). The nomenclature of integument sculpture follows HARRIS (1979).

\section{pilicornis species-group}

\section{Apenesia fusilis Côrrea \& Azevedo, 2001}

CÔRREA \& AZEVEDo (2001) described this species based on 31 specimens from Espírito Santo, Brazil, and now it is recorded for the first time to Paraná.

Material examined. BRAZIL, Paraná: 41 males, Colombo, EMBRAPA BR 476 km 20; 31 males São José dos Pinhais, Serra do Mar, BR 277 Km 54; 19 males, Telêmaco-Borba, Reserva Samuel Klabin; 10 males, Ponta Grossa, Vila Velha, Reserva IAPAR BR 376; 7 males, Jundiaí do Sul, Fazenda Monte Verde; 1 male, Fênix, Reserva Estadual ITCF; 1 male, Antonina, Reserva Sapitanduva; all 04.VIII. 1986-15.VIII.1988, Malaise trap, Profaupar survey (DZUP).

1) Departamento de Biologia, Universidade Federal do Espirito Santo. Avenida Marechal Campos 1468, Maruípe, 29040-090 Vitória, Espírito Santo, Brasil.

E-mail: mch@escelsa.com.br, cazevedo@npd.ufes.br 


\section{brasiliensis species-group \\ Apenesia transversa Evans, 1963}

Evans (1963) described this species based on a single specimen from Rio de Janeiro, Brazil. Evans (1966) recorded a new specimen from Santa Catarina, and now it is recorded for the first time to Paraná.

Material examined. BRAZIL, Paraná: 8 males, Colombo EMBRAPA BR 476 km 20; 1 male, São José dos Pinhais, Serra do Mar BR 277 Km 54; 21 males, Telêmaco-Borba, Reserva Samuel Klabin; 2 males, Ponta Grossa, Vila Velha, Reserva IAPAR BR 376; 11 males, Jundiaí do Sul, Fazenda Monte Verde; 1 male, Fênix, Reserva Estadual ITCF; all 15.VII.1986-15.VIII.1988, Malaise trap, Profaupar survey (DZUP).

\section{mexicana species-group}

\section{Apenesia quadrimera sp. $\mathbf{n}$.}

Figs 1-2

Description, male. Length $5.43 \mathrm{~mm}$; LFW $3.15 \mathrm{~mm}$.

Color. Head and mesosoma black; metasoma and mandible dark castaneous, antenna light castaneous, distal flagellomeres darker; legs, palpi and tegula light castaneous; wings hyaline.

Head (Fig. 1). Mandible with 4 sharpened apical teeth, the ventral one large and the subdorsal one very small. Clypeus with a triangular median lobe, bidentate, without median carina. First four antennal segments in a ratio of 28:7:13:12; segment III $1.86 \mathrm{X}$ as long as thick; segment XI $1.85 \mathrm{X}$ as long as thick; flagellar pubescence suberect, hairs slightly shorter than the thickness of segment. Eye with sparse and short hairs. Frons coriaceous, punctures shallow, scattered. WH $1.02 \mathrm{X}$ LH; WF $1.25 \mathrm{X}$ HE; OOL $0.93 \mathrm{X}$ WOT; frontal angle of ocelar triangle acute; posterior ocellus distant from the vertex crest $0.59 \mathrm{X} \mathrm{DAO}$. Vertex convex, corners rounded. VOL $0.36 \mathrm{X} \mathrm{HE}$.

Mesosoma (Fig. 1). Thoracic dorsum coriaceous. Pronotal disc with anterior transverse carina weak. Notauli complete, reaching both anterior and posterior margins of mesoscutum, parapsidal furrows incomplete anteriorly. Propodeal disc $1.05 \mathrm{X}$ as long as wide, weakly coriaceous, except on the basal triangle, with median and lateral carinae distinct, posterior carina very weak medially; basal triangle developed, striate, declivity without median carina, strongly coriaceous. Mesopleuron with callus coriaceous, with a few punctures. Fore wing without discoidal vein.

Metasoma. Sessile. Hypopygium slightly shorter than the stalk, posterior margin straight. Genitalia (Fig. 2): paramere very narrow on the base, apex very large, subquadrate, with apical margin concave, inferior inner corner angled, superior inner corner hairy; volsella with apex of dorsal ramus of digitus hairy, rounded and dilated, $1.5 \mathrm{X}$ as wide as the base, surpassing the apex of cuspis and digitus, and shorter than basal margin of paramere apex; aedeagus simple, median area slightly wider, with rounded lobes, as long as the inferior inner corner of the apex of the paramere. 


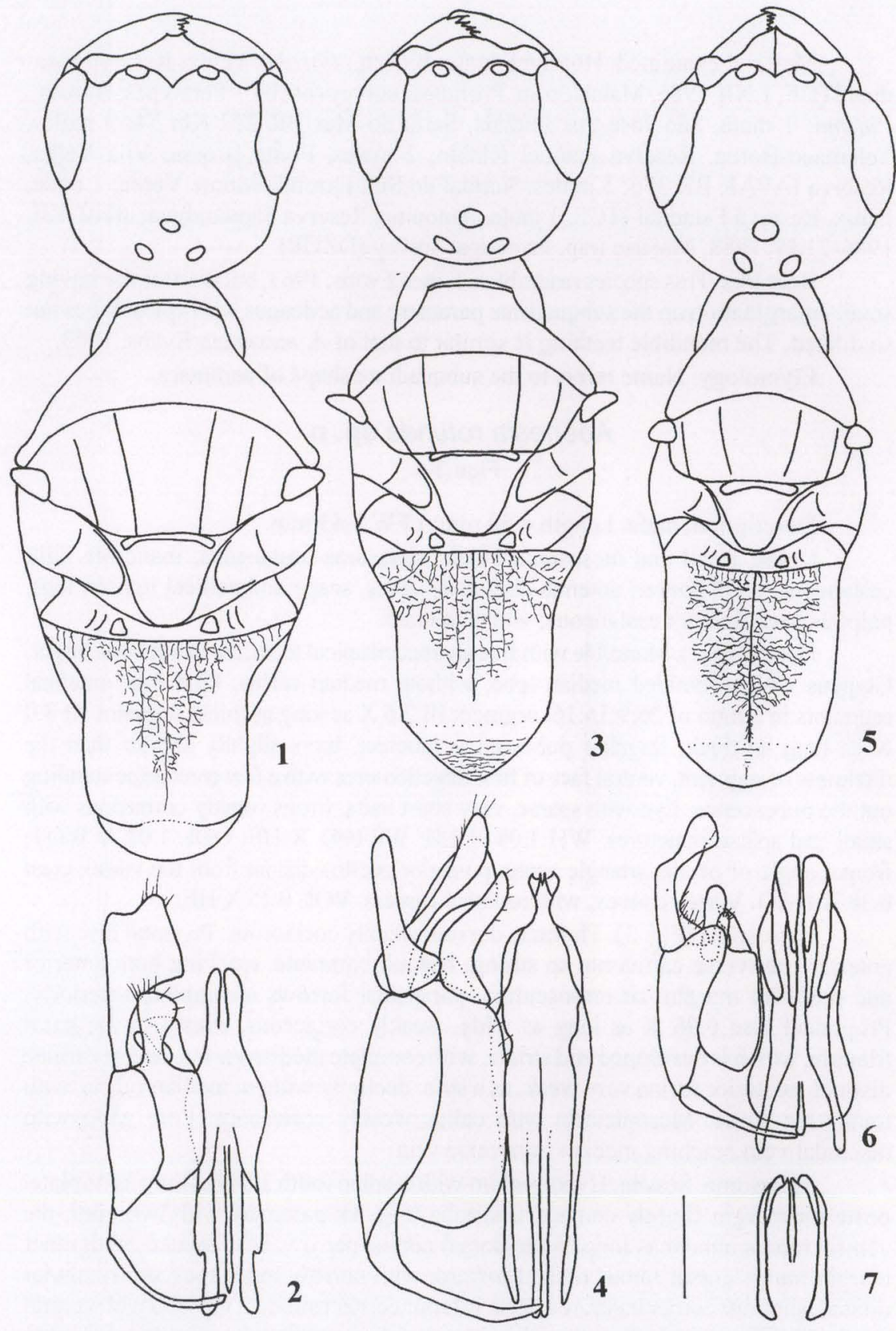

Figs 1-7. (1-2) Apenesia quadrimera sp. n.: (1) head and mesosoma, dorsal; (2) genitalia, ventral; (3-4) A. rotunda sp. n.: (3) head and mesosoma, dorsal; (4) genitalia, ventral; (5-7) A. clypeata sp. n.: (5) head and mesosoma, dorsal; (6) genitalia, ventral; (7) apex of aedeagus, dorsal. Body, scale bar $=0,35 \mathrm{~mm}$; genitalia, scale bar $=202 \mu \mathrm{m}$. 
Material examined. Holotype male, BrazIL, Paraná: Fênix, Reserva Estadual ITCF, 1.XII.1986, Malaise trap, Profaupar survey (DZUP). Paratypes: BRAZIL, Paraná: 1 male, São José dos Pinhais, Serra do Mar BR 277 Km 54; 3 males, Telêmaco-Borba, Reserva Samuel Klabin; 2 males, Ponta Grossa, Vila Velha, Reserva IAPAR BR 376; 5 males, Jundiai do Sul, Fazenda Monte Verde; 1 male, Fênix, Reserva Estadual ITCF; 1 male, Antonina, Reserva Sapitanduva; all 01.VII. 1986-21.IV.1988, Malaise trap, Profaupar survey (DZUP).

Remarks. This species resembles $A$. inca Evans, 1963, but it differs by having small emargination on the subquadrate paramere and aedeagus with apical lobes not so dilated. The mandible teething is similar to that of A. mexicana Evans, 1963.

Etymology. Name refers to the subquadrate shape of paramere.

\section{Apenesia rotunda sp. $\mathbf{n}$.}

Figs 3-4

Description, male. Length $4.58 \mathrm{~mm}$; LFW $3.43 \mathrm{~mm}$.

Color. Head and mesosoma black; metasoma castaneous; mandible light castaneous, teeth darker; antenna dark castaneous, scape and pedicel lighter; legs, palpi and tegula light castaneous; wings hyaline.

Head (Fig. 3). Mandible with five sharpened apical teeth, the ventral one larger. Clypeus with a rounded median lobe, without median carina. First four antennal segments in a ratio of 26:9:16:16; segment III $2.6 \mathrm{X}$ as long as thick; segment XI 3.0 $\mathrm{X}$ as long as thick; flagellar pubescence suberect, hairs slightly shorter than the thickness of segment, ventral face of first flagellomeres with a few erect setae standing out the pubescence. Eye with sparse, very short hairs. Frons weakly coriaceous with small and sparse punctures. WH 1.08 X LH; WF 0.91 X HE; OOL 1.02 X WOT, frontal angle of ocellar triangle acute; posterior ocellus distant from the vertex crest 0.38 X DAO. Vertex convex, with rounded corners. VOL 0.25 X HE.

Mesosoma (Fig. 3). Thoracic dorsum weakly coriaceous. Pronotal disc with anterior transverse carina not so strong. Notauli complete, reaching both anterior and posterior margins of mesoscutum, parapsidal furrows incomplete anteriorly. Propodeal disc $0.96 \mathrm{X}$ as long as wide, weakly coriaceous, except in the basal triangle, which is developed and striate, with complete median carina, lateral carinae distinct, posterior carina very weak, as a stria; declivity without median carina, with transverse striae. Mesopleuron with callus weakly coriaceous. Fore wing with discoidal vein reaching median transverse vein.

Metasoma. Sessile. Hypopygium with median tooth $2.0 \mathrm{X}$ as long as its plate, posterior margin slightly convex. Genitalia (Fig. 4): paramere with two rami, the ventral ramus almost as long as the dorsal ramus, narrow, base dilated, with inner margin hairy; dorsal ramus arched inward, with narrow base, apex subtriangular dilated, superior corner hairy, rounded, inferior corner rounded; volsella with ventral ramus of digitus longer than the inferior corner of paramere apex, margin hairy, base $2.0 \mathrm{X}$ more dilated than the rounded apex; aedeagus as long as ventral ramus of digitus, slightly wider medially, apex narrow with two slender lateral lobes and a pair of very slender median lobes. 
Material examined. Holotype male, BRAzIL, Paraná: Fênix, Reserva Estadual ITCF, 17.XI.1986, Malaise trap, Profaupar survey (DZUP). Paratypes: BRAZIL, Paraná: 2 males, São José dos Pinhais, Serra do Mar BR 277 Km 54; 1 male, Telêmaco-Borba, Reserva Samuel Klabin; 2 males, Jundiaí do Sul, Fazenda Monte Verde; all 01.IX.1986-04.VII.1988, Malaise trap, Profaupar survey (DZUP).

Etymology. Name refers to the rounded median lobe of clypeus.

\section{Apenesia distinta Corrêa \& Azevedo, 2001}

CORRÊA \& AZEVEDO (2001) described this species based on two specimens from Reserva Biológica de Duas Bocas, Espírito Santo, Brazil, and now it is recorded for the first time to Paraná. This species has its external morphology very similar to that of $A$. rotunda sp. n., but the genitalia has paramere deeply emarginated and apex of cuspis not reaching the apical margin of paramere.

Material examined. Brazil, Paraná: 22 males, São José dos Pinhais, Serra do Mar BR 277 Km 54; 1 male, Fênix, Reserva Estadual ITCF; 1 male, Colombo, EMBRAPA BR 476 km 20; all 06.VII.1987-25.VII.1988, Malaise trap, Profaupar survey (DZUP).

\section{Apenesia inca Evans, 1963}

Evans (1963) described this species from three specimens from Peru and Ecuador. Evans (1966) added two others specimens from Peru and three specimens from Santa Catarina, Brazil, and now it is recorded for the first time to Paraná.

Material examined. BrazIL, Paraná: 1 male, Colombo, EMBRAPA BR 476 km 20, 26.X.1987, Malaise trap, Profaupar survey (DZUP).

\section{Apenesia cusco Evans, 1966}

Evans (1966) described this species based on a single specimen from Peru and here it is recorded for the first time to Paraná.

Variations. Basivolsella tooth more slender and apex of paramere more arched inward than in the specimen described by Evans (1966).

Material examined. BrazIL, Paraná: 1 male, Colombo, EMBRAPA BR 476 km 20, 7.XII.1987, Malaise trap, Profaupar survey (DZUP).

\section{laevigata species-group}

\section{Apenesia clypeata sp. $\mathbf{n}$.} Figs 5-7

Description, male. Length $4.45 \mathrm{~mm}$; LFW $3.0 \mathrm{~mm}$.

Color. Head and mesosoma black; metasoma dark castaneous; mandible light castaneous, teeth darker, antenna light castaneous; flagellomeres darker; legs, palpi and tegula light castaneous; wings hyaline. 
Head (Fig. 5). Mandible with five small apical teeth, the ventral tooth slightly larger. Clypeus with subtriangular median lobe well developed, median carina complete, apical tooth small. First four antennal segments in a ratio of 23:6:21:18; segment III $2.1 \mathrm{X}$ as long as thick; segment XI $3.2 \mathrm{X}$ as long as thick; flagellar pubescence semi-erect, as long as thickness of segment. Eye with sparse and short hairs. Frons polished, shinning, punctures shallow, sparse. WH 1.0 X LH; WF 1.11 X HE; OOL 1.36 X WOT; frontal angle of ocellar triangle acute; posterior ocellus distant from the vertex crest $0.29 \mathrm{X}$ DAO. Vertex and corners even and broadly rounded. VOL $0.19 \mathrm{X} \mathrm{HE}$.

Mesosoma (Fig. 5). Thoracic dorsum smooth, shinning. Pronotal disc without anterior transverse carina; notauli incomplete, not reaching both anterior and posterior margins of mesoscutum, parapsidal furrows incomplete anteriorly. Propodeal disc $0.93 \mathrm{X}$ as long as wide, smooth, shinning, except on the basal triangle, with median and lateral carinae distinct, posterior carina absent; basal triangle developed, striate, declivity without median carina, polished, with weak transverse striae medially. Mesopleuron smooth, shinning, weakly punctured. Fore wing with discoidal vein very faint, interstitial with median vein.

Metasoma. Petiolate. Hypopygium $1.25 \mathrm{X}$ as long as its plate, posterior margin straight. Genitalia (Figs 6-7): paramere with base wide, inner margin hairy, apex gibbose, outer margin of apex concave, outer corner angled; volsella with ventral ramus of digitus short, evenly thick, apex rounded, shorter than the cuspis, basivolsella developed basally; aedeagus as long as the outer corner of paramere, slightly wider medially, apex with a pair of dilated ventral lobes, and a pair of slender, shorter dorsal lobes (Fig. 7).

Material examined. Holotype male, BRAzIL, Paraná: Telêmaco-Borba, Reserva Samuel Klabin, 21.III.1988, Malaise trap, Profaupar survey (DZUP). Paratypes: BrazIL, Paraná: 4 males, Telêmaco-Borba, Reserva Samuel Klabin; 8 males, Jundiaí do Sul, Fazenda Monte Verde; 1 male, Fênix, Reserva Estadual ITCF; 2 males, Antonina, Reserva Sapitanduva; all 01.IX.1986-25.VII.1988, Malaise trap, Profaupar survey (DZUP).

Variations. Mandible pale castaneous; declivity of propodeum smooth to weakly coriaceous, with or without transverse striae.

Remarks. This species is very similar to A. crenulata (Kieffer, 1910), which is known only from the type from Pará, Brazil.

Etymology. Name refers to the large clypeus.

\section{columbana species-group}

\section{Apenesia funebris Evans, 1963}

EVANS (1963) described this species based on two specimens from Rio de Janeiro and Santa Catarina, Brazil, and now it is recorded for the first time to Paraná.

Material examined. Brazil, Paraná: 12 males, Colombo, EMBRAPA BR 476 km 20; 1 male, São José dos Pinhais, Serra do Mar BR 277 Km 54; 1 male, Telêmaco-Borba, Reserva Samuel Klabin; 14 males, Jundiaí do Sul, Fazenda Monte 
Verde; 3 males, Antonina, Reserva Sapitanduva; all 04.VIII.1986-27.VI.1988, Malaise trap, Profaupar survey (DZUP).

Variations. Mandible usually black, but pale in specimens with teeth dark castaneous and antenna with scape darker than the other segments. Punctures of head varying from deep to shallow. Declivity of varying from wholly smooth to smooth with transverse striae.

ACKNOWLEGDEMENT. To Laboratory of Genetics (UFES) for the loan of the microscope used to illustrate the genitalia; the curator K. Zanol (DZUP) for the loan the material examined.

\section{REFERENCES}

Corréı, M.S. \& C.O. Azevedo. 2001. Taxonomia de Apenesia (Hymenoptera, Bethylidae) da Reserva Biológica de Duas Bocas, Espírito Santo, Brazil. Iheringia, Sér. Zool., 90: 167-174.

Evans, H.E. 1963. A revision of the genus Apenesia in the Americas (Hymenoptera, Bethylidae). Bull. Mus. Comp. Zool. 130 (4): 249-359.

- 1966. Further studies on Neotropical Pristocerinae (Hymenoptera, Bethylidae). Acta Hymenopterol. 2 (3): 99-117.

Gordh, G. \& L. Moczar. 1990. A catalog of the world Bethylidae (Hymenoptera). Mem. Amer. Entomol. Inst. 46: 1-364.

HARRIS, R.A. 1979. A glossary of surface sculpturing. Oce. Pap. Entomol. 28: 1-31.

Recebido em 14.XI.2000; aceito em 06.VII.2001. 